\title{
Water Quality in Wyoming - The Sage Creek Project
}

\author{
By Mark D. Shirley
}

Travelers crossing south-central Wyoming on Interstate 80 may notice that the normally clear waters of the North Platte River have turned a murky brown color. The probable cause: an intense thunderstorm in the Sage Creek Basin resulting in high sediment levels in this tributary of the river. Sage Creek's impact on water quality in the North Platte River, a blue-ribbon fishery, has been a concern for many years.

In 1997, the Saratoga-Encampment-Rawlins (SER) Conservation District received a Section 319 Grant funded by the Environmental Protection Agency (EPA) to implement Best Management Practices (BMP's) within the basin. The grant also provided funding for various forms of monitoring to track progress towards improving water quality in Sage Creek and reducing the sediment contribution to the North Platte River. A Steering Committee consisting of landowners and personnel from the Conservation District, Natural Resources Conservation Service (NRCS), Bureau of Land Management (BLM), Wyoming Game \& Fish Department, University of Wyoming Cooperative Extension Service, Carbon County, and the City of Rawlins provide guidance for project implementation. The project is administered under the Nonpoint Source Pollution Program of the Wyoming Department of Environmental Quality (DEQ).

Sage Creek originates along the Continental Divide at an elevation of $8,400 \mathrm{ft}$. flowing in an easterly direction to its confluence with the North Platte River at approximately $6,600 \mathrm{ft}$. in elevation. Average annual precipitation ranges from 7-9 inches at the lower elevations to more than 20 inches

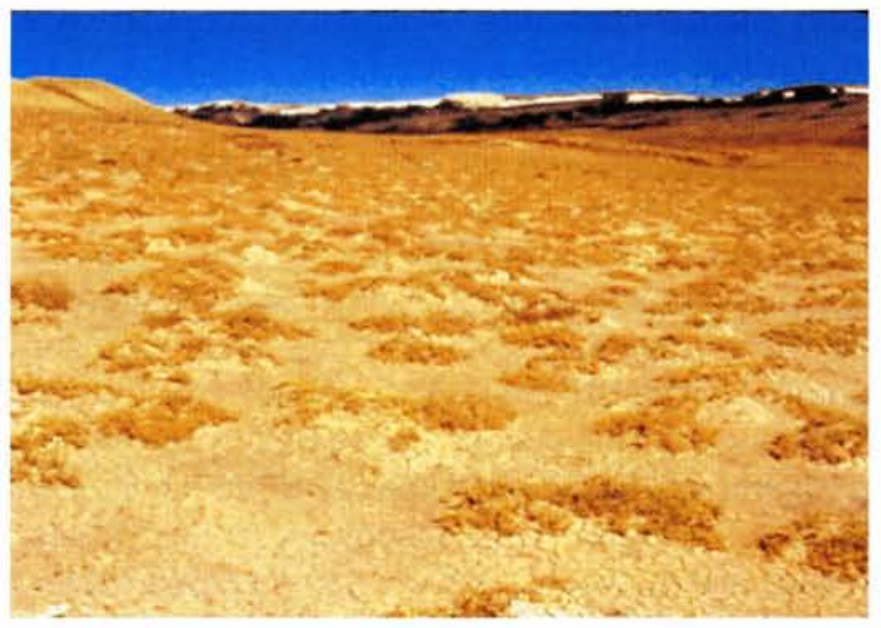

Upland site typical of the Sage Creek Basin. Gardner's saltbush is the dominant plant with a high amount of bare ground. Infiltration rates are low on these sites with clay soils resulting in high runoff and sedimentation rates.

near the Continental Divide. The oval shaped watershed is approximately 188,000 acres in size and is almost completely surrounded by a rock rim.

Vegetation communities within the basin include mountain shrub at higher elevations with pockets of aspen in swales that receive additional moisture. Sagebrush steppe dominates large areas at intermediate elevations. Salt-desert shrub sites, with minimal plant cover and considerable bare ground, occur on extensive areas within the basin. Greasewood shrub communities are found in the alkaline lowland areas adjacent to the streams. Deep snowdrifts that accumulate in the draws along the Continental Divide provide runoff during the spring and early summer.

Sage Creek has been listed on Wyoming DEQ's 303(d) list as an impaired stream. In 1996 there were in excess of 360 streams on this list, many having been placed there based on subjective evidence. It became apparent, when EPA was sued to force development of Total Maximum Daily Loads (TMDL's) for each stream on the list, that there was a need to gather credible data to determine which waterbodies were actually impaired.

Wyoming's 34 Conservation Districts stepped forward and offered to help with the task of collecting scientific and credible data on the streams in question. A 5-phase training program was developed to standardize sampling methods and train personnel on sampling techniques, including data analysis and 
interpretation. The Conservation Districts worked closely with landowners/stakeholders associated with streams on the impaired list by providing education and information on water quality.

\section{Early History}

Early explorers venturing through the area provided a glimpse of the landscape before settlement by European man. Howard Stansbury, an Army Topographical Engineer, crossed Sage Creek approximately 4 miles above its confluence with the North Platte River in September of 1850. Stansbury's description of Sage Creek and the surrounding area is as follows: "The water is eight feet wide, and three or four inches deep, with free current, and vertical clay banks. After crossing Sage Creek, we encountered many ravines coming down from a ridge on our right, the intervening ground being washed almost entirely bare of grass or vegetation of any kind".

Another account, by F.T. Bryan, who was searching for a suitable wagon route through the area in August of 1856, describes the following: "The country over which we passed is a good deal broken and water washed, and miserably poor and desolate. It is almost entirely destitute of vegetation except the sage plant, and an occasional tuft of grass, the intervals being quite bare. The surface is much cut up by gullies and ravines."

\section{Geology and Soils}

Geologically, the Sage Creek Basin was formed near the close of the Cretaceous Period. A vast western interior seaway that covered the area during this period resulted in sedimentary deposits according to Knight. Alternating beds of shale and sandstone were deposited when the sea advanced and retreated a number of times. Del Mauro reported that during the late Tertiary Period, mountain glaciers discharged highly erosive flows across the landscape, resulting in formation of the present drainage system. Erosion from these flows is easily discernable in the southwest portion of the basin. Streams lost their erosive power with the retreat of the glaciers, resulting in aggrading channels with fine sediment.

The Sage Creek Basin is unlike other tributaries to the North Platte River in this area because of soils and local geology. Soils in the area developed from sedimentary and alluvial parent material including the unstable Niobrara Shale formation. Sheet and rill erosion, occurring on soils derived from marine shales, contribute sediment to Sage Creek and its tributaries resulting in high levels of suspended sediment and colloidal clays. The NRCS conducted a soil survey of the basin that included assigning an erosion hazard rating. Soils with a "Severe" erosion hazard comprise $28 \%$ of the basin. An additional $51 \%$ of the soils are classified as "Moderate to Severe", revealing that a majority of the watershed is highly susceptible to erosion.

\section{Erosion and Sedimentation}

Suspended sediment within a stream occurs from two sources: upland erosion and channel erosion. One goal of the monitoring, in addition to tracking the effectiveness of BMP implementation, is to better understand sources of sedimentation and how the sediment moves through the system. When a stream system is stable and able to carry a given sediment load with its current yearly discharge pattern, the system is said to be in dynamic equilibrium. Skinner reports that stream channels move through a successional sequence. Due to stream flow dynamics, a limited amount of sediment can be stored before erosional processes start to remove it. Sediment tends to move in pulses as influenced by runoff and flow events. Sediment eroded at one location may be stored temporarily and subsequently remobilized several times before reaching the drainage outlet according to Walling.

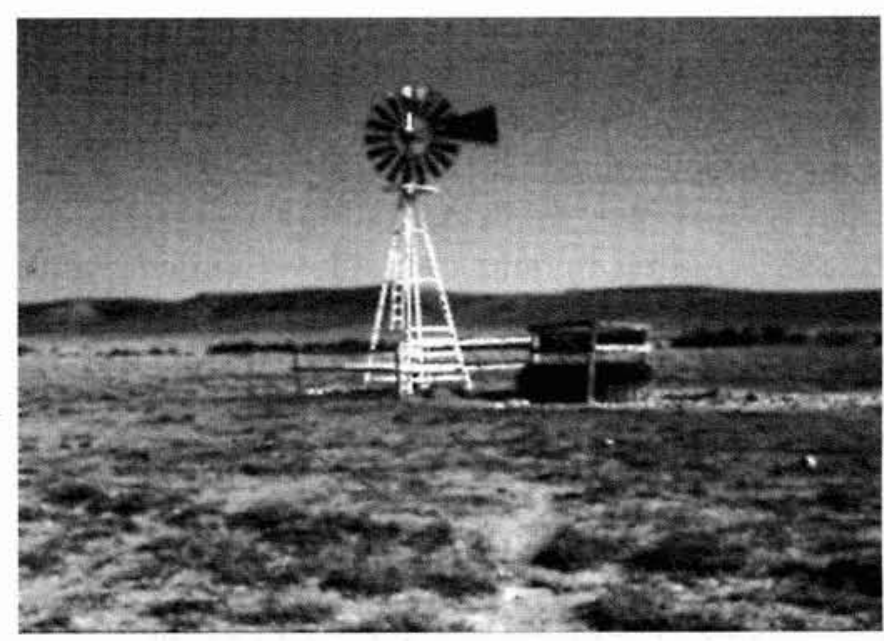

Upland water developments allow for improved livestock grazing distribution and reduce impacts to riparian areas. 


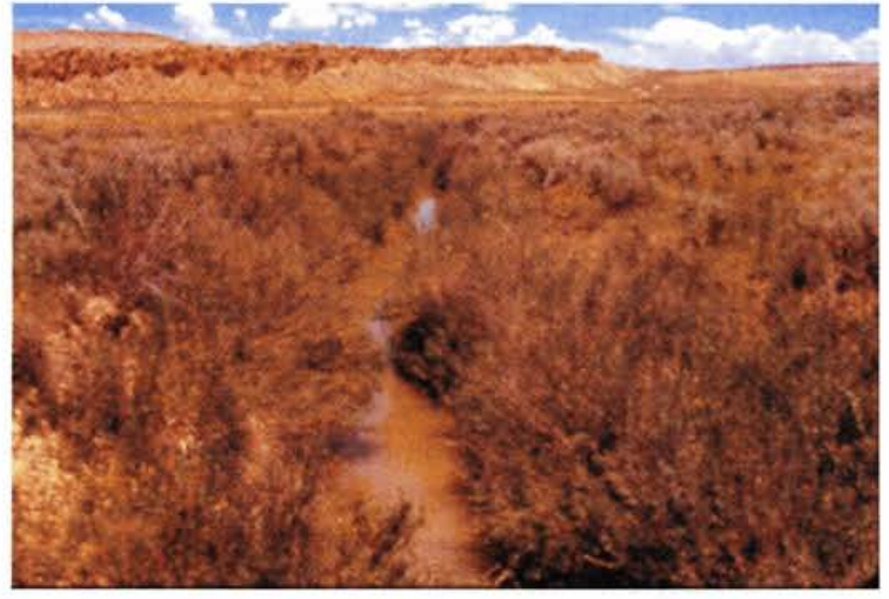

Improved riparian area on Sage Creek. A change in the grazing system has provided a recovery period for plants during the growing season resulting in an increase of woody species such as willows.

Riparian landscapes are important in terms of water quality. Vegetation within these areas influences the flows of water, sediment, and nutrients through the hydrologic system. Vegetation is important in stabilizing streambanks, dissipating energy, trapping sediment, and filtering nutrients. Goertler found that improved riparian vegetation effectively trapped sediment and controlled nonpoint source pollution on Muddy Creek in Carbon County, Wyoming. Grazing management systems that provide for healthy riparian areas are effective in reducing nonpoint source pollution.

\section{Implementation of Best Management Practices}

An important aspect of the Sage Creek Project has been the implementation of a planned grazing system in a majority of the watershed. The length of grazing periods has been shortened allowing longer recovery periods. Implementation of the grazing system required upland water developments and cross-fencing. These practices also lessened grazing pressure on riparian areas. An increase in woody species within the riparian zone, in particular willows, has occurred with the change in grazing management.

Another practice being implemented is modifications to road crossings. Board fences have also been installed on an experimental basis to evaluate the ability to trap blowing snow and supplement early season water for both livestock and wildlife. Grade control structures and reservoirs both on and offchannel provide for a reduction in flow velocities thereby allowing for sediment to settle out of suspension. Monitoring above and below these structures revealed a decrease in suspended sediment. Native hay meadows can also serve as filters where vegetation removes sediment from diverted water before re-entering the creek as return flow.

A monitoring system has been established to collect additional baseline data and track the effectiveness of BMP implementation. The monitoring program includes: chemical water quality and benthic macroinvertebrate sampling, channel cross-sections, riparian photo-points, green-line transects, and upland biological transects. A majority of the monitoring sites were established in 1998. The project has received additional funding, and monitoring will continue through 2004. The long-term data set should serve to capture some of the natural variability associated with nonpoint source pollution.

\section{Discussion}

Measurement of nonpoint source pollution is difficult because of its diffuse nature and inherent variability. Monitoring has revealed the "flashy" nature of Sage Creek in relation to precipitation events. Dramatic increases in flows and sediment concentrations occur in response to precipitation events, particularly summer thunderstorms. A combination of clay soils with low infiltration rates and incised channels contribute to peaks in the hydrograph during storm events. A large percentage of total season sediment discharge can occur in a few days as a result of one precipitation event (Fig. 1).

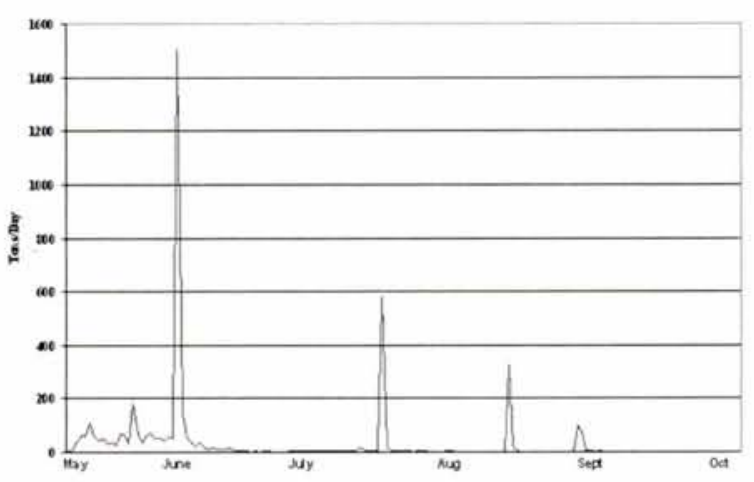

Fig. 1. Estimated Sediment Discharge from Sage Creek in 1999. The spike in discharge on June $15^{\text {th }}$ occurred in response to a 0.39 inch rainfall event. 
Grade control structures and off-channel reservoirs serve to capture these peak flows and allow for sediment to settle out of suspension resulting in an improvement in water quality and lower sediment contributions to the North Platte River. Healthy riparian areas, in which vegetation traps sediment, also function to improve water quality.

Based on the accounts of early explorers, upland vegetative cover has always been low with high rates of erosion. While high rates of sedimentation appear to occur naturally in the Sage Creek Basin, current land use activities can and do affect water quality. Implementation of planned grazing systems, cross-fencing, upland water development, modifications to road-crossings, and grade control structures all serve to reduce the sediment entering the creek and allow for improvement to riparian areas. Will Sage Creek ever be a blue-ribbon fishery? No, we doubt it, but we do hope to continue with improvements that will reduce the amount of sediment contribution to the North Platte River, which is a blue-ribbon fishery.

\section{References}

Bryan, F.T. 1858. Report on the wagon road survey from Fort Riley to Bridger Pass. $35^{\text {th }}$ Cong., $1^{\text {st }}$ Sess., Senate Exec. Doc. No. 11, Vol. II, p. 455-520, Serial 920.

Del Mauro, D.L. 1953. Geology of Miller Hill and Sage Creek area, Carbon County, Wyoming. M.S. Thesis, Univ. of Wyoming. Laramie, Wyo.

Goertler, C.M. 1992. Sediment dynamics within channel and riparian zone types along a cold-desert Wyoming stream. M.S. Thesis. Univ. of Wyoming. Laramie, Wyo.

Knight, S.H. 1990. Illustrated geologic history of the Medicine Bow Mountains and adjacent areas, Wyoming. The Geologic Survey of Wyoming. Memoir No. 4.

Skinner, Q.D., K.K. Crane, J.G. Hiller, and J.D. Rodgers. 2000. Wyoming watersheds and riparian zones. Univ. of Wyoming Cooperative Extension Service, Laramie, Wyo.

Stansbury, H. 1852. Exploration and survey of the valley of the Great Salt Lake of Utah, including a reconnaissance of a new route through the Rocky Mountains. $32^{\text {nd }}$ Cong. Spec. Sess. , Senate Exec. Doc. N. 3. Serial 608.

USDA-SCS. 1979. Sage Creek Basin Watershed Investigation Report. Platte River Basin Cooperative Study. Casper, Wyo.

USDA-SCS. 1972. Soil survey of the Sage Creek Watershed.

Walling, D.E. 1994. Measuring sediment yields from river basins. p. 40-44. In: R. Lal. (ed), Soil erosion research methods, $2^{\text {nd }}$ Ed. Soil and Water Conservation Society. Ankeny, lowa.

The author is a Rangeland Management Specialist with the Natural Resources Conservation Service, P.O. Box 6, Medicine Bow, WY 82329. During the first phase of the project, he was the District Coordinator, SER Conservation District, Saratoga, WY.

This project was funded by the Wyoming Department of Environmental Quality, Contract \#ONO38. 